\title{
KEMAMPUAN VISUAL SPASIAL SISWA DALAM MENYELESAIKAN SOAL PISA KONTEN SHAPE AND SPACE BERDASARKAN GAYA BELAJAR
}

\author{
Nur Isnaini ${ }^{1}$, Titik Sugiarti ${ }^{2}$, Lioni Anka Monalisa ${ }^{2}$, Dinawati Trapsilasiwi ${ }^{2}$, \\ Ervin Oktavianingtyas ${ }^{2}$ \\ Program Studi Pendidikan Matematika, FKIP, Universitas Jember \\ Jalan Kalimantan 37 Kampus Tegalboto Jember 68121 \\ E-mail: nurisnaini326@gmail.com
}

\begin{abstract}
This study aims to describe students' spatial-visual ability in solving PISA questions in shape and space content based on visual, auditory, and kinesthetic learning styles. This type of research used in this research is descriptive qualitative research. Subjects in the study were six students from Class X MIPA 3 SMA Negeri 2 Tanggul consisting of two students from each of the visual, auditory and kinesthetic learning styles. The data collection methods used were questionnaires, tests, and interviews. The instruments used in this study were learning style questionnaires, shape and space content PISA test questions, and interview guidelines. The results showed that the achievement of the characteristics of the sixth spatial-visual abilities of the subjects differed. Students with a visual learning style can meet the characteristics of pattern search, conceptualization, problem-solving, and imagination in full. Students with an auditory learning style can meet the characteristics of conceptualization, problem-solving, and imagination completely but are unable to meet the characteristics of pattern search. Students with kinesthetic learning styles meet the characteristics of problem solving and imagination but are unable to meet indicators on the characteristics of pattern search and conceptualization. This can be seen from the results of solving the questions given and interviews conducted on the research subjects.
\end{abstract}

Keyword: Spatial-Visual Ability, PISA Questions on Shape and Space Content, Learning Style

\section{PENDAHULUAN}

Pendidikan merupakan sarana terpenting untuk membentuk generasi yang bermanfaat terhadap kemajuan dan perkembangan suatu bangsa. Tujuan pendidikan secara umum adalah untuk meningkatkan kualitas diri menjadi pribadi yang mampu bersaing dan menjawab berbagai tantangan di masa depan [1]. Salah satu mata pelajaran yang berperan penting dalam kehidupan manusia untuk mengembangkan potensinya adalah mata pelajaran matematika.

Belajar matematika akan lebih berhasil jika pembelajaran diarahkan kepada konsepkonsep dan struktur yang termuat dalam pokok bahasan yang diajarkan dengan alat peraga untuk meningkatkan keaktifan siswa [2]. Dalam pembelajaran matematika realistik,

\footnotetext{
${ }^{1}$ Mahasiswa S1 Prodi Pendidikan Matematika FKIP Universitas Jember

${ }^{2}$ Dosen Prodi Pendidikan Matematika FKIP Universitas Jember
} 
matematika tidak dipandang sebagai ilmu atau bidang kajian yang sudah jadi, tetapi dipandang sebagai sesuatu yang harus dibangun sendiri oleh siswa sehingga siswa akan menjadi subjek belajar yang aktif dalam menemukan dan membangun idenya sendiri [3]. Secara garis besar, matematika memiliki empat cabang yaitu Aritmatika, Aljabar, Geometri, dan Analisis. Salah satu hal yang penting dalam matematika adalah pembelajaran geometri dimana geometri mendukung segala aspek yang memiliki peran dalam kemampuan pemecahan masalah. Pembelajaran geometri berkaitan dengan bangun dimensi dua maupun dimensi tiga, mempelajari geometri menuntut siswa menggunakan imajinasinya menentukan posisi dan ukuran suatu objek dalam ruang [4].

Kecerdasan majemuk pada manusia yang dikemukakan oleh Gardner, yaitu kecerdasan verbal linguistik, kecerdasan logika matematika, kecerdasan visual spasial, kecerdasan kinestetik, kecerdasan musikal, kecerdasan interpersonal, kecerdasan intrapersonal, kecerdasan naturalis [5]. Salah satu kemampuan yang menarik untuk diteliti dalam penelitian ini adalah kemampuan visual spasial karena kemampuan tersebut dimiliki seseorang dalam menyelesaikan permasalahan geometri. Kemampuan visual spasial adalah kemampuan yang mencakup kemampuan berpikir dalam gambar, kemampuan untuk menyerap, mengubah, dan menciptakan kembali berbagai macam aspek dunia visual spasial. Kemampuan visual spasial juga berkaitan dengan kemampuan menangkap warna, arah, dan ruang secara akurat [6].

Terdapat empat karakteristik yang dapat digunakan untuk mendeskripsikan kemampuan visual-spasial yaitu pengimajinasian, pengkonsepan, pemecahan masalah, dan pencarian pola. Keempat karakteristik tersebut sangat terlihat pada peserta didik dengan kemampuan visual-spasial yang tinggi [7]. Dengan demikian, empat karakteristik ini yang digunakan sebagai indikator penelitian untuk mengukur tingkat kemampuan visual spasial siswa.

Setiap individu memiliki cara menyerap informasi yang berbeda dalam memahami suatu permasalahan. Perbedaan dalam menyerap informasi ini disebut dengan gaya belajar. Gaya belajar seseorang adalah kombinasi dari bagaimana ia menyerap, kemudian mengatur, dan mengolah informasi. Tipe-tipe gaya belajar dibagi menjadi tiga bagian berdasarkan modalitas. Modalitas yang dimaksud adalah visual, auditori, dan kinestetik. Berdasarkan hal tersebut dapat dikatakan bahwa modalitas yang dimaksud adalah indra dan kemampuan dasar manusia [8]. 
Upaya untuk menguji tingkat berpikir geometri siswa dalam mengembangkan kemampuan visual spasial berdasarkan gaya belajar yang sesuai dengan perkembangan zaman, maka diperlukan instrumen untuk menciptakan kemampuan siswa dapat bersaing dengan dunia internasional. Pengembangan soal matematika di era globalisasi ini mengacu pada soal Program for Internasional Student Assesment (PISA) content Shape and Space. Tujuan penelitian ini dilakukan untuk mendeskripsikan kemampuan visual spasial siswa dalam menyelesaikan soal PISA konten shape and space berdasarkan analisis kemampuan visual spasial siswa berdasarkan gaya belajar visual, auditorial, dan kinestetik. Indikator kemampuan visual spasial dapat dilihat pada Tabel 1.

Tabel 1. Indikator Karakteristik Kemampuan Visual Spasial

\begin{tabular}{cl}
\hline Karaktertistik & \multicolumn{1}{c}{ Indikator } \\
\hline Pencarian pola & $\begin{array}{l}\text { Menemukan dan menggunakan pola dalam menyelesaikan } \\
\text { permasalahan geometri }\end{array}$ \\
\hline Pengkonsepan & $\begin{array}{l}\text { Menggunakan konsep dengan benar dan menghubungkan } \\
\text { data dengan konsep yang telah dimiliki untuk menyelesaikan } \\
\text { permasalahan geometri }\end{array}$ \\
\hline Pemecahan & $\begin{array}{l}\text { Menggunakan ide-ide dalam menyelesaikan permasalahan } \\
\text { masalah }\end{array}$ \\
\hline geometri \\
\hline
\end{tabular}

\section{METODE PENELITIAN}

Jenis penelitian ini adalah penelitian deskriptif dengan pendekatan kualitatif. Metode pengumpulan data yang digunakan adalah metode angket, tes, dan wawancara. Instrumen yang digunakan berupa angket gaya belajar, soal tes PISA konten shape and space, dan pedoman wawancara. Penelitian dilaksanakan pada tanggal 8 dan 9 Januari 2020 kepada 34 siswa kelas X MIPA 3 SMA Negeri 2 Tanggul. Pengumpulan data diperoleh dengan cara memberikan angket gaya belajar yang disusun oleh O'Brien yang diterjemahkan untuk mengelompokkan siswa kedalam gaya belajar visual, auditorial atau kinestetik. Pengelompokkan tersebut dipilih dua siswa dari masing-masing gaya belajar. Langkah selanjutnya dilakukan tes kemampuan visual spasial yang terdiri dari empat soal yang didapat dari modifikasi soal-soal PISA konten shape and space. Hasil tes kemampuan visual spasial kemudian dianalisis untuk mengkategorikan kemampuan visual spasial siswa berdasarkan gaya belajar. Instrumen penelitian mencapai kriteria valid jika nilai $4 \leq V_{a} \leq 5$. 
Ketiga instrumen tersebut pada kriteria valid, sehingga dapat dilanjutkan pada tahap pengumpulan data. Data diperoleh dari hasil angket gaya belajar dan soal tes PISA konten shape and space. Tahap analisis data dilakukan terhadap hasil tes dan wawancara.

\section{HASIL DAN PEMBAHASAN}

Hasil analisis angket menunjukkan bahwa masing-masing tipe gaya belajar dapat ditemukan pada kelas tersebut. Berdasarkan hasil analisis terhadap 34 siswa, 6 diantaranya memiliki tipe gaya belajar campuran. Penelitian ini menekankan kepada siswa yang memiliki tipe gaya belajar tunggal sebanyak 28 siswa, dengan rincian 9 siswa memiliki tipe gaya belajar visual, 14 siswa memiliki tipe gaya belajar auditorial, dan 5 siswa memiliki tipe gaya belajar kinestetik. Dari data yang diperoleh, dipilih dua siswa dari masing-masing gaya belajar. Berdasarkan analisis data yang telah dilakukan, dapat diketahui dari enam subjek penelitian berdasarkan gaya belajar yaitu SV1 (Siswa Visual 1), SV2 (Siswa Visual 2), SA1 (Siswa Auditorial 1), SA2 (Siswa Auditorial 2), SK1 (Siswa Kinestetik 1), dan SK2 (Siswa Kinestetik 2).

\section{a. Analisis Karakteristik Pencarian Pola}

Instrumen soal tes PISA konten shape and space pada karakteristik pencarian pola adalah sebagai berikut.

Berikut ini diagram yang menunjukkan pola penanaman pohon apel dan pohon pinus, $n$ menyatakan banyaknya pohon apel yang ditanam.

$\times=$ Pohon pinus $\quad \bullet=$ Pohon apel

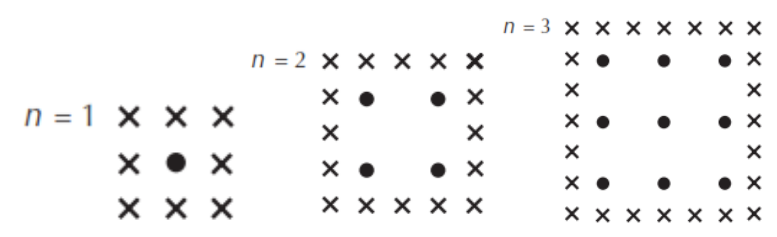

a. Lengkapilah tabel di bawah ini !

\begin{tabular}{|c|c|c|}
\hline $\mathbf{N}$ & Banyaknya pohon apel & Banyaknya pohon pinus \\
\hline 1 & 1 & 8 \\
\hline 2 & 4 & $\ldots$ \\
\hline$\cdot$ & $\cdot$ & $\cdot$ \\
$\cdot$ &. &. \\
\hline $\mathrm{N}$ & $\ldots$ & $\ldots$ \\
\hline
\end{tabular}

b. Pohon manakah yang akan bertambah atau tumbuh dengan cepat? Jelaskan!

Pada karakteristik pencarian pola subjek SV1 sudah mampu menemukan pola dengan cara mencari hubungan antara $n$, banyaknya pohon apel dan pohon pinus. Begitu pula 
dengan subjek SV2 mampu menemukan pola dengan melihat pola awal pada gambar. Hal ini sesuai dengan penelitian relevan mengatakan bahwa siswa dengan tipe gaya belajar visual lebih cepat memahami materi matematika jika menggunakan gambar, diagram, grafik [9]. Selain itu, subjek dengan tipe gaya belajar visual juga dapat menjawab pertanyaan peneliti dengan baik saat dilakukan wawancara. Berikut jawaban siswa visual dapat dilihat pada Gambar 1.

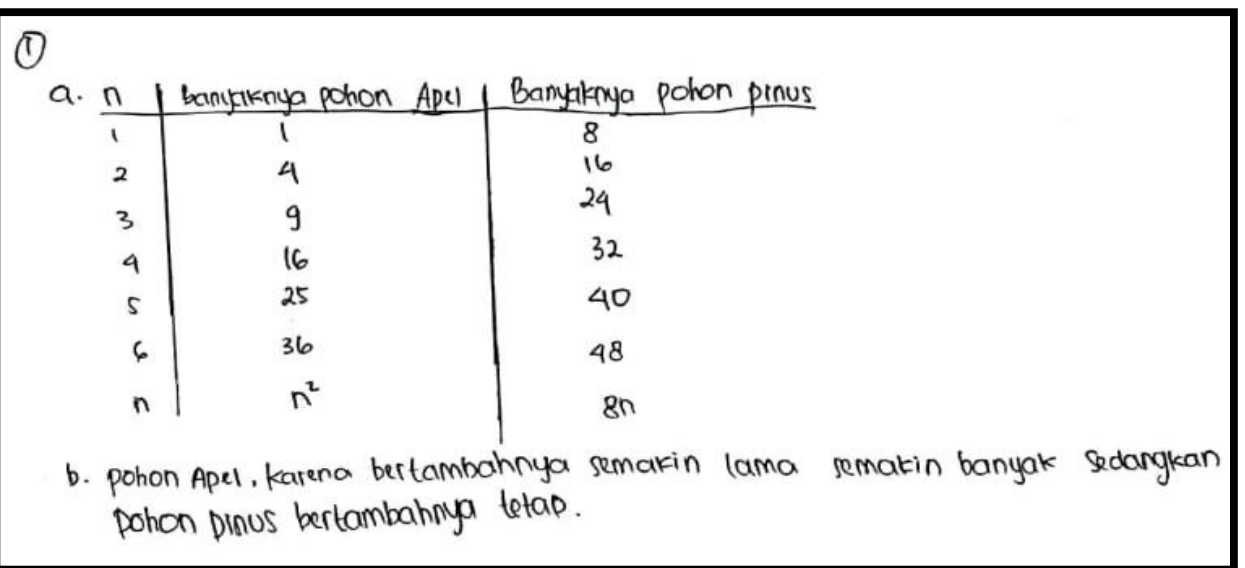

\section{Gambar 1. Jawaban SV1 pada Karakteristik Pencarian Pola}

Subjek SA1 dan SA2 bisa menemukan pola yang dicari tetapi tidak dapat memahami maksud dari pola tersebut sehingga jawaban poin $b$ tidak tepat. Berdasarkan uraian hasil tes dan hasil wawancara, subjek SA1 dan SA2 tidak memenuhi karakteristik pencarian pola karena siswa mampu menemukan pola tetapi tidak mampu menggunakan pola dalam menyelesaikan permasalahan geometri. Hal ini sejalan dengan penelitian yang relevan yang mengemukakan bahwa siswa dengan tipe gaya belajar auditorial hanya mampu mengolah informasi dengan menunjukkan penggunaan rumus yang telah dituliskannya, tetapi kurang mampu menyimpan dan mengingat informasi selama proses perencanaan dan pelaksanaan penyelesaian [10]. Berikut jawaban siswa auditorial dapat dilihat pada Gambar 2. 
(1.) a.) $\pi /$ Banyaknya pohon apel $/$ Banyaknya pohon pinus

\begin{tabular}{|c|c|c|}
\hline 1 & Banyaknya pohon ape & Banyaknya pohon pinus \\
\hline 2 & 1 & 8 \\
\hline 3 & 4 & 16 \\
\hline 4 & 9 & 24 \\
\hline 5 & 16 & 32 \\
\hline 6 & 25 & 40 \\
\hline 7 & 36 & 48 \\
\hline 8 & 49 & 56 \\
\hline$n$ & 64 & 64 \\
\hline
\end{tabular}

b.) Pohon pinus kafena Petani jika ingin menanam 9 pohon apel itu membutuhkan 24 pohon pinus yang ditanam sebagai pagar untuk melindungi pohon apel dari goncangan angin. Jad artinya jika petani ingin menanam pohon apel dan pohon plnus maka para petani harus mempertimbangkan jumlah masing - masing pohon, Jadi Pohan apel itu Jumlahnya tidak boleh melebihi Jumlah pohon pinus, karena Jika Jumlahnya mejebihi pohon pinus, Pohon apel tersebut akan terkena guneangan angin akibat pohon pinus yang tulak muat untuf melindungi pohon apel tersebut makadori to Jumlah pohon pinus hares lebih banyak.

\section{Gambar 2. Jawaban SA1 pada Karakteristik Pencarian Pola}

Subjek SK1 dan SK2 sudah mampu menemukan pola, namun tidak mampu menjelaskan hubungan dari pola yang ditemukan. Hal ini sejalan dengan penelitian relevan yang mengemukakan bahwa kendala siswa dengan tipe gaya belajar kinestetik dalam tes kemampuan spasial siswa belum mampu memahami gambar untuk menjawab pertanyaan dan belum mampu memecahkan masalah yang melibatkan simbol dan gambar [11]. Berikut jawaban siswa kinestetik dapat dilihat pada Gambar 3.

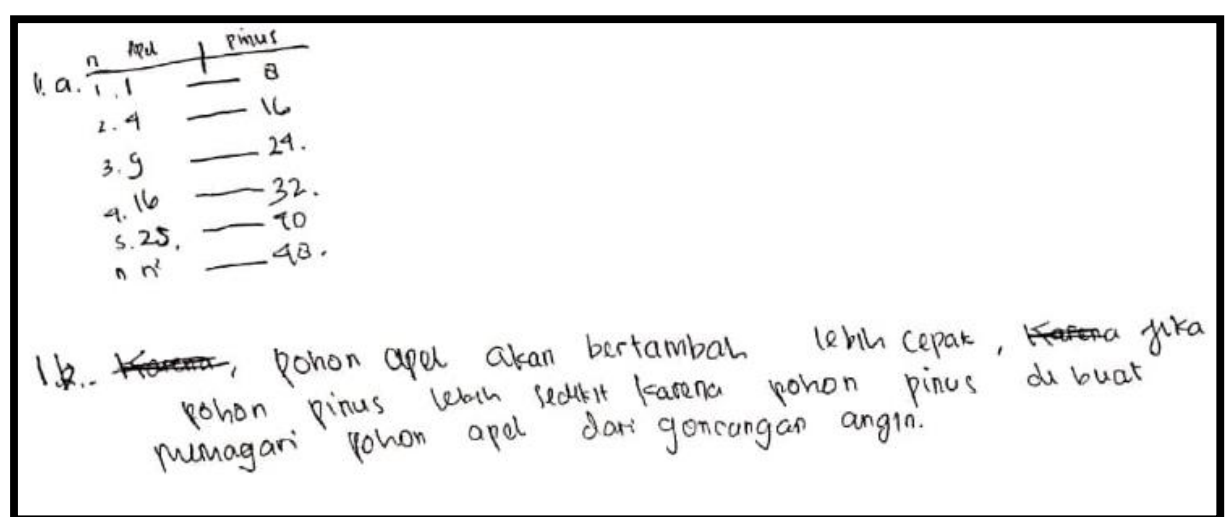

Gambar 3. Jawaban SK1 pada Karakteristik Pencarian Pola

\section{b. Analisis Karakteristik Pengkonsepan}

Instrumen soal tes PISA konten shape and space pada karakteristik pengkonsepan adalah sebagai berikut.

George memilih model garasi sederhana dengan dua sketsa dalam ukuran meter (m) sebagai berikut. 


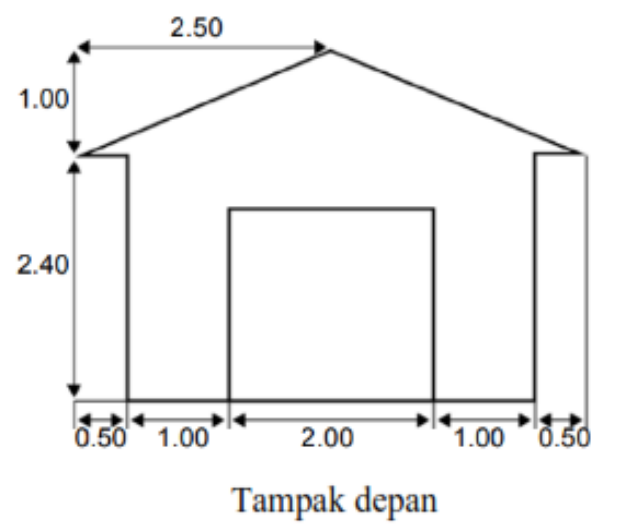

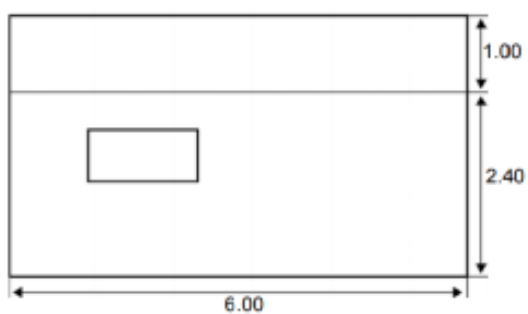

Tampak samping

Atap garasi terbentuk dari dua persegi panjang yang identik. Hitunglah luas atap garasi tersebut!

Pada karakteristik pengkonsepan subjek SV1 menyelesaikan dengan menggunakan konsep rumus Pythagoras dan luas persegi panjang serta mampu menghubungkan data yang diketahui dengan konsep yang dimiliki. Analisis hasil tes subjek SV2 ada penulisan pada langkah pengerjaan yang kurang tepat tetapi SV2 mampu memberikan jawaban akhir dengan benar. Berdasarkan uraian hasil tes dan hasil wawancara subjek SV1 dan SV2 memenuhi karakteristik pengkonsepan karena siswa mampu menggunakan dan menghubungkan antara data yang diketahui dengan konsep yang dimiliki. Hal ini sesuai dengan penelitian relevan yang mengatakan bahwa siswa dengan tipe gaya belajar visual melaksanakan langkahlangkah penyelesaian diawali dengan mengolah informasi yaitu mengaitkan data-data untuk menentukan rumus yang digunakan [10]. Selain itu, hal tersebut juga sejalan dengan penelitian relevan yang berpendapat bahwa siswa dengan tipe gaya belajar visual mampu mengekspresikan ide-ide yang dimilikinya dengan rapi dan teratur sesuai dengan pengetahuan dan informasi yang diperolehnya sehingga siswa mampu menyelesaikan dan menjawab permasalahan dengan sangat baik [12]. Berikut jawaban siswa visual dapat dilihat pada Gambar 4.

$$
\text { (2) } \begin{aligned}
& L=\sqrt{2,5^{2}+1^{2}} \\
&=\sqrt{6.25+1} \\
&=\sqrt{7.25} \\
&=2,65 \\
& p=6,00 \\
& \text { Latap }=2 \text { Lpersegi } \\
&=2 p \times l \\
&=2.600 \times 2,65 \\
&=31.8 \mathrm{~m}
\end{aligned}
$$




\section{Gambar 4. Jawaban SV1 pada Karakteristik Pengkonsepan}

Subjek SA1 dan SA2 sudah mampu menentukan konsep apa saja yang akan digunakan dalam menyelesaikan soal, tetapi subjek SA1 belum memahami soal secara keseluruhan sehingga jawaban akhir tidak tepat sedangkan subjek SA2 mampu memahami soal secara keseluruhan sehingga jawaban akhir dengan tepat. Subjek SA1 dan SA2 memenuhi karakteristik pengkonsepan karena siswa mampu menggunakan konsep dengan benar dan mampu menghubungkan antara data yang tersedia dengan konsep dimiliki untuk menyelesaikan permasalahan geometri. Hal ini sesuai dengan penelitian relevan yang mengatakan bahwa siswa dengan tipe gaya belajar auditorial mampu mendefinisikan rumusrumus matematika karena memang telah didiskusikan dan telah ia ketahui sebelumnya [12]. Berikut jawaban siswa auditorial dapat dilihat pada Gambar 5.

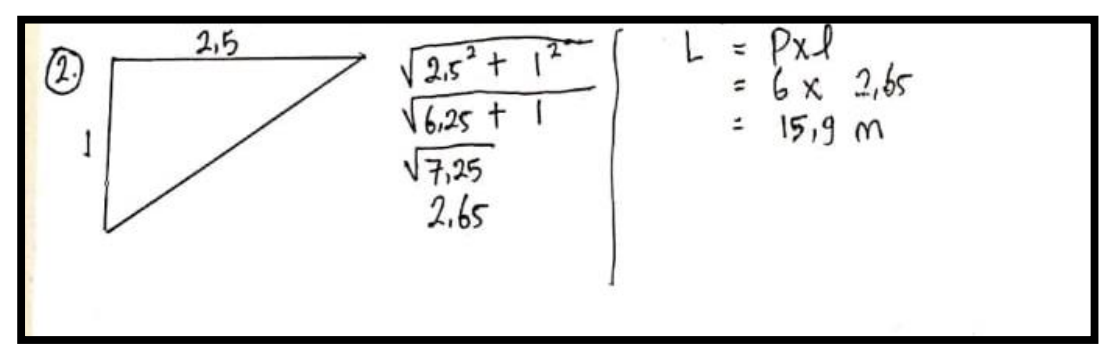

Gambar 5. Jawaban SA1 pada Karakteristik Pengkonsepan

Subjek SK1 maupun SK2 sudah mampu memahami soal namun karena ada satu konsep lain yang tidak diketahui sehingga jawaban akhir tidak tepat. subjek SK1 dan SK2 sudah mampu menentukan konsep luas persegi panjang saja tetapi tidak memahami konsep Pythagoras untuk menyelesaikan permasalahan tersebut. Berdasarkan uraian hasil tes dan hasil wawancara, subjek SK1 dan SK2 tidak memenuhi karakteristik pengkonsepan karena tidak mampu menggunakan konsep dengan benar dan belum mampu menghubungkan antara data yang tersedia dengan konsep dimiliki dalam menyelesaikan permasalahan geometri. Siswa bergaya belajar kinestetik mencoba menyelesaikan soal dengan strategi coba-coba dan sering kali salah konsep karena kurang paham maksud soal jika hanya dibayangkan, hal ini sesuai dengan penelitian relevan yang mengatakan siswa bergaya belajar kinestetik punya keinginan melakukan segala hal (mencoba hal baru) dan lebih suka belajar menggunakan alat peraga atau media pembelajaran [9]. Berikut jawaban siswa kinestetik dapat dilihat pada Gambar 6. 


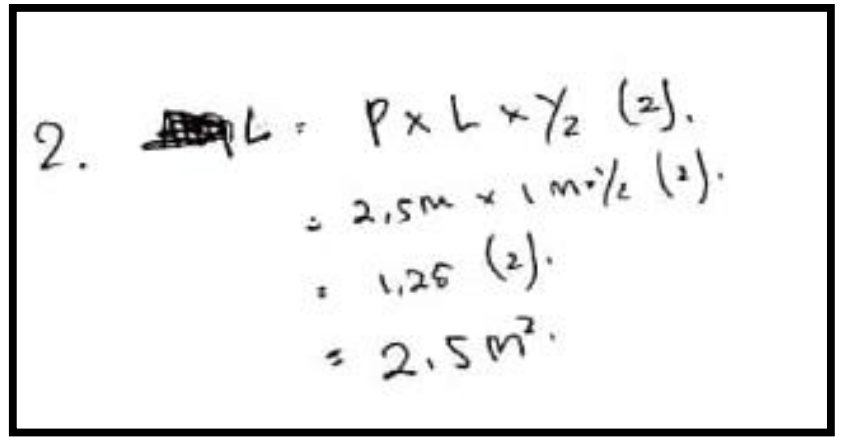

Gambar 6. Jawaban SK1 pada Karakteristik Pengkonsepan

\section{c. Analisis karakteristik pemecahan masalah}

Instrumen soal tes PISA konten shape and space pada karakteristik pemecahan masalah adalah sebagai berikut.

Sebuah pintu putar terdiri dari 3 daun pintu yang berputar dalam ruangan yang berbentuk lingkaran. Diameter pada ruangan ini adalah $2 \mathrm{~m}$. Ketiga daun pintu membagi ruangan menjadi tiga bagian yang sama besar.

a. Berapakah ukuran sudut yang dibentuk oleh dua buah daun pintu?

b. Berapakah panjang busur maksimal dari masing-masing pintu (pintu masuk dan pintu keluar) yang dapat dibuat agar aliran udara dapat keluar masuk dengan mudah melalui pintu tersebut?

Pada karakteristik pemecahan masalah subjek visual, subjek auditorial, maupun subjek kinestik mampu menggunakan idenya dan langkah-langkah pengerjaan yang hampir sama. Subjek visual dapat menentukan strategi untuk menghitung panjang busur maksimal agar udara dapat keluar masuk dengan menentukan besar sudutnya terlebih dahulu. Subjek visual menggali informasi pada soal dengan melakukan proses perhitungan dan menggambar sketsanya. Hal ini sesuai dengan penelitian relevan yang mengemukakan bahwa siswa dengan tipe gaya belajar visual mampu menggambarkan sketsa berdasarkan permasalahan yang ada pada soal [12]. Subjek auditorial mampu menyelesaikan semua langkah dengan benar dan mampu memberikan jawaban akhir secara tepat. Hal ini sesuai dengan penelitian relevan yang mengemukakan bahwa siswa dengan tipe gaya belajar auditorial dapat membuat rencana penyelesaian [10]. Subjek kinestetik kurang teliti dalam mengerjakan sehingga hasil akhirnya ada jawaban yang tidak tepat. Hal ini sesuai dengan penelitian relevan yang mengemukakan bahwa siswa dengan tipe gaya belajar kinestetik belum mampu menyusun penyelesaian, namun saat wawancara subjek kinestetik mampu memberikan penjelasan penyelesaian masalah disertai dengan alasan yang tepat [11]. Berikut jawaban siswa visual dapat dilihat pada Gambar 7. 


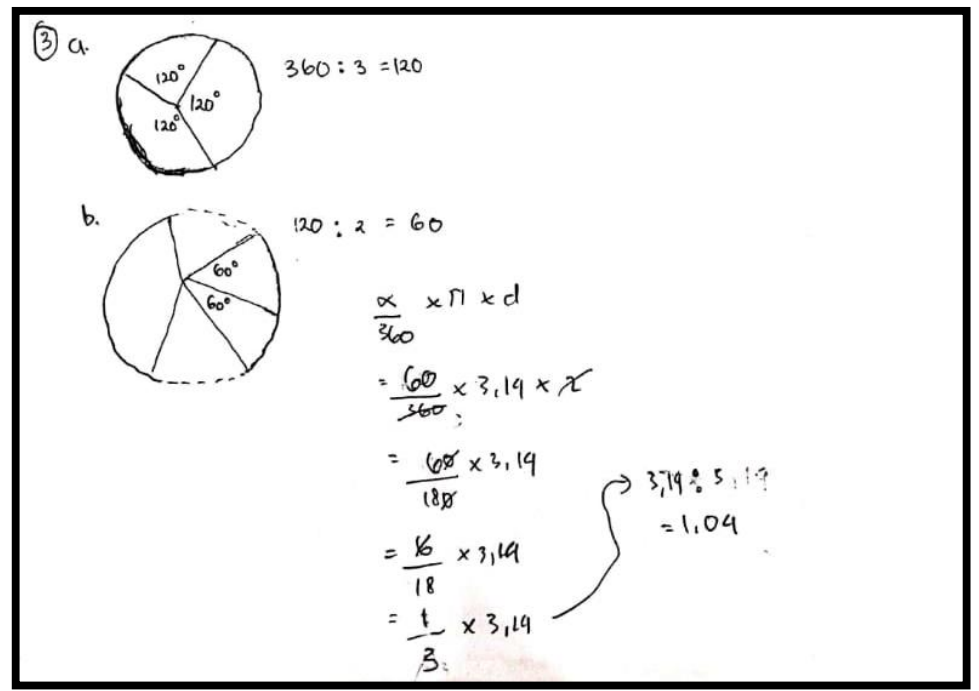

Gambar 7. Jawaban SV1 pada Karakteristik Pemecahan Masalah

\section{d. Analisis karakteristik pengimajinasian}

Instrumen soal tes PISA konten shape and space pada karakteristik pengimajinasian adalah sebagai berikut.

Dadu adalah sebuah kubus bernomor spesial di setiap sisinya yang mengikuti aturan sebagai berikut: jumlah titik di dua sisi yang berlawanan selalu 7 .

Pada gambar di bawah ini, Anda dapat melihat empat potongan yang dapat digunakan untuk membuat dadu dengan titik-titik di setiap sisi-sisinya. Yang manakah dari potonganpotongan tersebut yang jika dilipat dapat memenuhi aturan bahwa jumlah titik di sisi-sisi yang berlawanan adalah 7 ?
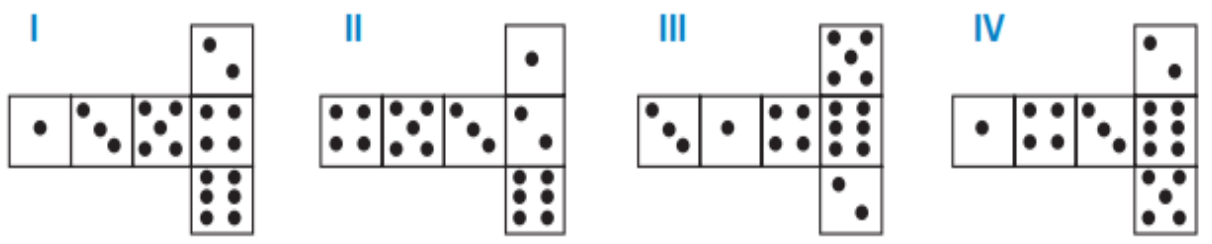

Pada karakteristik pengimajinasian subjek visual, subjek auditorial, maupun subjek kinestik mampu menentukan gambar bentuk lain yang akan digunakan untuk menyelesaikan permasalahan pada soal. Hal tersebut ditunjukkan oleh subjek penelitian dapat memahami gambar yang diberikan dan dapat mengimajinasikan gambar sesungguhnya kemudian menggunakannya dalam menyelesaikan masalah [14]. Subjek visual mampu membayangkan posisi titik-titik yang sesuai jika potongan-potongan dadu menjadi sebuah dadu. Hal ini sesuai dengan penelitian relevan yang mengatakan bahwa siswa yang memiliki tipe gaya belajar visual dapat berpikir secara tiga dimensi, menggambarkan bagaimana tiba di tempat atau dengan mudah mendesain produk dalam kepala mereka [9]. Subjek dengan 
tipe gaya belajar auditorial dapat menjelaskan proses membayangkan ketika melihat potongan-potongan dadu menjadi dadu dengan posisi titik-titik yang sesuai. Hal ini sesuai dengan penelitian relevan yang mengatakan bahwa seseorang dengan tipe gaya belajar auditorial mampu menjelaskan sesuatu panjang lebar meskipun merasa kesulitan untuk menulis namun hebat dalam bercerita [9]. Subjek dengan tipe gaya belajar kinestetik dapat menjelaskan secara detail pertanyaan peneliti terkait hasil pekerjaannya yang membayangkan semua jaring-jaring dadu terlebih dahulu. Saat wawancara, subjek kinestetik menggunakan telunjuknya untuk membaca soal dan menyebutkan informasi apa saja yang terdapat pada soal. Hal ini sesuai dengan penelitian relevan yang mengemukakan bahwa seseorang dengan tipe gaya belajar kinestetik biasanya menggunakan jari sebagai penunjuk ketika membaca [9]. Berikut jawaban siswa visual dapat dilihat pada Gambar 8.

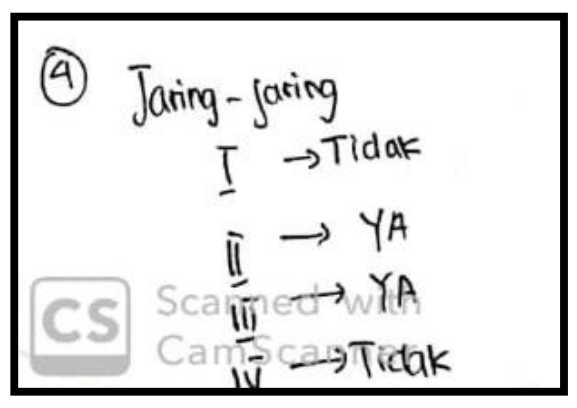

\section{Gambar 8. Jawaban SV1 pada Karakteristik Pengimajinasian}

Pada penelitian ini karakteristik kemampuan visual spasial pada keenam subjek penelitian dijabarkan pada Tabel 2.

Tabel 2. Karakteristik Kemampuan Visual Spasial pada Subjek Penelitian

\begin{tabular}{ccccccc}
\hline Karakteristik Kemampuan & \multicolumn{7}{c}{ Subjek Penelitian } \\
\cline { 2 - 7 } Visual Spasial & V1 & V2 & A1 & A2 & K1 & K2 \\
\hline Pencarian pola & $\checkmark$ & $\checkmark$ & $\times$ & $\times$ & $\times$ & $\times$ \\
\hline Pengkonsepan & $\checkmark$ & $\checkmark$ & $\checkmark$ & $\checkmark$ & $\times$ & $\times$ \\
\hline Pemecahan masalah & $\checkmark$ & $\checkmark$ & $\checkmark$ & $\checkmark$ & $\checkmark$ & $\checkmark$ \\
\hline Pengimajinasian & $\checkmark$ & $\checkmark$ & $\checkmark$ & $\checkmark$ & $\checkmark$ & $\checkmark$ \\
\hline
\end{tabular}

\section{Keterangan :}

$\checkmark \quad$ :Memenuhi $\quad \times \quad$ :Tidak memenuhi

Secara keseluruhan pencapaian karakteristik kemampuan visual spasial siswa dalam setiap gaya belajar dalam penelitian ini dominan siswa mampu dalam membayangkan objek yang menjadi permasalahan, namun tidak semua siswa dalam penelitian ini mampu untuk penggunaan konsep. Hasil wawancara yang didapatkan dari siswa masih merasa kesusahan 
menggunakan pola dalam menyelesaikan permasalahan. Hal tersebut sependapat dengan penelitian relevan yang mengatakan bahwa karaktertistik kemampuan visual spasial pada karakteristik pengimajinasian dan pemecahan masalah adalah karakter yang paling dominan (paling banyak dipenuhi) diantara yang lainnya [15].

\section{KESIMPULAN}

Berdasarkan hasil dan pembahasan dapat disimpulkan bahwa pada karakterisitik pencarian pola subjek visual dapat menemukan pola dengan melihat susunan gambar, sedangkan subjek auditorial dan subjek kinestetik dapat menemukan pola dengan tepat namun kesulitan dalam menjelaskan penggunaan pola. Pada karakteristik pengkonsepan subjek visual dan subjek auditorial dapat menerapkan konsep serta menghubungkan antara data dan konsep yang dimiliki, sedangkan subjek kinestetik hanya mampu menghubungkan satu konsep saja dan ada konsep lain yang tidak dipahami sehingga hasil pengerjaan tidak benar. Pada karakteristik pemecahan masalah dan pengimajinasian subjek visual, subjek auditorial, maupun subjek kinestik mampu menggunakan idenya dan menentukan gambar bentuk lain yang akan digunakan untuk menyelesaikan permasalahan pada soal.

\section{DAFTAR PUSTAKA}

[1] Undang-Undang Republik Indonesia Nomor 20 Tahun 2003. Sistem Pendidikan Nasional. 8 Juli 2003. Lembaran Negara Republik Indonesia Tahun 2003. Nomor 4301. Jakarta

[2] Suherman, E. (2003). Strategi Pembelajaran Matematika Kontemporer. Bandung: Jurusan Pendidikan MIPA Universitas Pendidikan Indonesia.

[3] Sugiarti, T. (2002). Pembelajaran Matematika dengan Pembelajaran Realistik. Jurnal Ilmu Pendidikan MIPA dan MIPA, 3 (1): 1-8.

[4] Fathoni, L. (2013). Profil Kecerdasan Visual-Spasial Siswa dalam Memahami Gambar Bangun Ruang yang Tersusun dari Beberapa Bangun Kubus. Gamatika, 3(2), 155-161.

[5] Gardner, H. (1983). Frames of Mind: The Theory of Multiple Intelligences. New York: Basic Books.

[6] Haris, A., \& Rahman, A. (2018). Kemampuan Spasial Mahasiswa Melalui Pembelajaran Berbasis Masalah Dengan Software Geogebra. Prosiding Seminar Nasional, 1-7. http://ejournal.mandalanursa.org/index.php/Prosiding/article/view/376

[7] Haas, Steven C. (2003). Algebra for Gifted Visual-Spatial Learners, Gifted Education Communication (Spring), 34(1), 30-31; 42-43.

[8] Meylino, R. (2018). Analisis Miskonsepsi Siswa Sekolah Dasar dalam Menyelesaikan Soal Matematika Materi Pecahan Ditinjau dari Gaya Belajar. Jember. Digital Repository Universitas Jember.

[9] Deporter, B \& Hernacki, M. (2016). Quantum Learning: Membiasakan Belajar Nyaman dan Menyenangkan. Bandung: Kaifa 
[10] Tiffani, H. (2015). Profil Proses Berpikir Siswa SMP dalam Menyelesaikan Soal Perbandingan berdasarkan Gaya Belajar dan Gaya Kognitif. Jurnal Kependidikan Dasar. 1(1): 7-21.

[11] Juliani, D. (2018). Analisis Kemampuan Siswa Kinestetik dalam Pemecahan Masalah Matematika pada Materi Bangun Ruang Kelas VIII MTsN 4 Kota Jambi. Skripsi. Universitas Jambi.

[12] Mufida, M. (2015). Analisis Kemampuan Komunikasi Matematis pada Model PBL dengan Pendekatan Saintifik Berdasarkan Gaya Belajar Siswa Kelas VIII. Skripsi. Universitas Negeri Semarang.

[13] Librianti, V. D., Sunardi, and Sugiarti, T. (2015). Kecerdasan Visual Spasial dan Logis Matematis dalam Menyelesaikan Masalah Geometri Siswa Kelas VIII A SMP Negeri 10 Jember (Visual Spatial and Logical Mathematical Intelligence in Solving Geometry Problems Class VIII A SMP Negeri 10 Jember). Artik. Ilm. Mhs., vol. 1, pp. 1-7.

[14] Rohmah, K. A. (2017). Kecerdasan Visual Spasial Siswa dalam Memecahkan Masalah Geometri Bangun Ruang Sisi Datar Kelas VIII SMP Nuris Jember. Jember: Digital Repository Universitas Jember. 